\title{
30-second politics, 30 years too late: Political TV advertising in Swedish election campaigns, 2006-2018
}

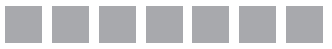 \\ Marie Grusell \\ ORCID: 0000-0001-5502-6126
}

UNIVERSITY OF GOTHENBURG, SWEDEN

Lars Nord

ORCID: 0000-0002-1363-7778

MID SWEDEN UNIVERSITY, SWEDEN

DOI: 10.19195/1899-5101.12.3(24).1

\begin{abstract}
Televised political advertising appears in very different national political communication contexts. Sweden is an interesting case study. For many years, political ads on TV were not allowed at all. However, with the transition from analog to digital terrestrial television the public service obligations of the "hybrid" channel TV4 were dismantled. In the 2010 national election campaign, all Swedish parliamentary parties bought advertising time on TV4. This article intends to shed new light on political TV ads as a new campaign feature in a rapidly transforming political communication environment. The study relates to the concept of hybridization of election campaigns and intends to increase knowledge about hybridization processes by focusing on a critical case where one of the most adopted campaign practices worldwide is finally implemented within a specific national context and deviating political culture.
\end{abstract}

KEYWORDS: political advertising, television, Sweden, election campaigns, hybridization.

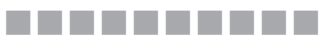

\section{INTRODUCTION}

Political TV ads are a central element in election campaign communication in many countries, and especially in the US (Kaid \& Holtz-Bacha, 2006; Holtz-Bacha, 2018). TV ads are perceived as an effective communication channel during election campaigns. First of all, this is because TV spots normally reach a high number of citizens with party or candidate designed political messages unfiltered by news media. Second of all, as most previous studies in this area confirm, they have an 
important role in increasing political knowledge among the public and mobilizing the electorate (Holbert et al., 2002; Kaid, 2008; Fridkin \& Kenney, 2012).

Political communication studies of political TV ads during election campaigns have so far mostly focused on mass communication perspectives and are based on the assumption that television is the single most important political information channel for citizens. Arguments about the effectiveness and electoral impact of political TV ads are also to a large extent embedded in a mass communication campaign context. Consequently, the role of political TV ads in the contemporary digital and increasingly hybrid media landscape is less explored, and especially the late introduction of spots in such campaign contexts. There are reasons to believe that politicians and political parties perceive this communication channel differently when the total number of available arenas for communication with voters has increased dramatically in the digital media landscape and when some of these arenas also offer hitherto unknown interactive possibilities.

This article investigates Swedish political party attitudes toward political TV ads and discusses the implications for strategic political party communications when traditional communication channels are introduced in highly digitalized campaign contexts and mixed with contemporary campaign practices and tools. The case of the late introduction of political TV advertising in Sweden in 2006 may shed new light on the phenomenon of hybridization of election campaign strategies and the understanding of how different party campaign features are mixed.

The next section provides an overview of the development of political TV advertising in Sweden. A literature review follows, offering different perspectives on hybrid campaigning and political TV advertising and a presentation of the study, methodology and results. In the final section, different aspects of the mixture of traditional and digital communication channels are discussed.

\section{THE STORY OF POLITICAL TV ADVERTISING IN SWEDEN}

Sweden deviates from the pattern as a country rapidly moving away from a very restrictive to a very liberal position on political TV ads in a few years (Grusell \& Nord, 2010). Political ads in Swedish television were prohibited on the main terrestrial national TV channels until 2009. However, recent decades have seen the emergence of a gradual transformation process mainly explained by structural media technology developments (Engblom \& Wormbs, 2007; Nord, 2008). Due to the planned switchoff of the analog TV broadcast system in 2007 a majority of Swedish households were offered a huge number of digitally distributed channels in 2006. Some of these channels were not regulated within the existing Radio and TV Act with regard to political "neutrality." Consequently, domestic "niche" channels could send political spots (Engblom \& Wormbs, 2007).

In the 2009 European Parliament (EP) election campaign, the debate about political TV advertising became more intense. For the first time ever, political spots 
were allowed on the main national TV channel (TV4). In the national election campaign in 2010, all parliamentary parties decided to purchase political advertising space in TV4. Generally, there was now something resembling "hype" around this campaign tool. Finally, in the latest national election campaigns in 2014 and 2018, political TV advertising turned out to be less explicitly discussed by political parties. This communication channel was now more carefully implemented and integrated in all overall campaign strategies and practices. Most parties have produced ads for television, Internet and social media, but parties with more limited campaigns decided to only produce ads on less expensive digital media platforms.

A chronological review of the status of political TV advertising in Sweden may be summarized as follows: a cautious introduction in niche channels before the national elections in 2006, a polarized debate before the EP elections in 2009, a wide acceptance before the national elections in 2010, and finally, a more pragmatic approach before the national elections in 2014 and 2018.

\section{PERSPECTIVES ON HYBRID CAMPAIGNING}

Opinion climates and media landscapes are not what they used to be. General conditions of election campaigns in modern democracies are changing, highly influenced by voter preference changes such as declining party identification and de-alignment of the electorate (Karvonen \& Kuhnle, 2001; Dalton, 2008). Political attitudes seem to be less formed by collective loyalties and socio-demographics and increasingly influenced by individual preferences. Voter volatility and the rapidly changing party landscapes are distinctive features of contemporary democracies. In the new media environment, campaign communications become more diverse; media use more individual and audiences are more fragmented (Brants \& Voltmer, 2011; Magin et al., 2017).

This transformation is to a large extent technology-driven and new campaign tools and digital devices are implemented in the campaign in order to make it more efficient in targeting relevant voter segments (Negrine \& Stanyer, 2007; Skirbekk, 2015). Campaign techniques and practices are spread and further developed in election campaigns worldwide and the characteristics of election campaigns are gradually transformed from a mass audience perspective to an individual audience perspective (Magin et al., 2017). The most distinctive feature of this transformation is probably the breakthrough of digital communications (Blumler, 2013; Grusell \& Nord, 2016). From a political communication perspective, digitalization has facilitated strategic party and candidate communication and improved the potential for interactions between politicians and citizens (Chadwick \& Stromer-Galley, 2016; Jungherr, 2016). Election campaigns are transforming as parties and candidates try to adopt to new structural campaign conditions. Some political actors may be more successful than others in capitalizing on these changes and they may be implemented into existing campaign strategies and practices with varying success. Consequently, a mixture of old and new communication features tends to appear in the 
campaign, differently combined by different political actors (Swanson \& Mancini, 1996; Plasser \& Plasser, 2002; Chadwick, 2013).

In political communication literature on election campaigns, these processes have often been referred to as processes of hybridization (Plasser \& Plasser, 2002; Esser \& Pfetsch, 2004; Chadwick, 2013). The term is used to catch a process where campaign features of different nature and origin merge into new patterns. The hybridization process is assumed to be influenced by global campaign experiences and innovations, new technology, national laws and regulations, political culture and voter characteristics. So far, the main perspective in hybridization studies has been to analyze and compare how international campaign trends develop within specific national political communication contexts (Plasser \& Plasser, 2002; Nord, 2009).

Still, election campaign transformations are more evolutionary than revolutionary in nature. Innovations and new initiatives are implemented but in most cases appear side by side with established campaign practices and communication channels. Ads banners on party websites do not replace advertising in traditional media, but political messages on the web may be calibrated, tailored and directed toward more specific groups of voters. In general, new communication practices and tools in an election campaign are introduced gradually. There might be a media "hype" about every new digital platform, but more interesting is probably to ask how new campaign features are implemented in overall campaign structures and strategies. Several studies in political communication in recent years have focused on the adoption of new campaign elements in existing electoral contexts and tried to answer why some innovations have been successfully implemented and why others have failed. The most common perspective has been party implementations of social media platforms in their campaign arsenal (Towner \& Dulio, 2012; Lilleker et al., 2014).

The analytical point of departure for this study is slightly different. While there is growing interest and knowledge about how new campaign practices influence party campaigning, there is limited research about how old campaign features influence party campaigning when, more or less anachronistically, introduced in modern, digital campaign contexts. What happens to existing campaign structures and campaign strategies in such situations? To what extent are party perceptions of old - but in this specific case new - campaign tools influenced by recent transformations of election campaign conditions?

Thus, the objective of this article is to analyze how political TV advertising develops as a campaign tool when introduced within an already highly digital communication context. Does it turn into a more or less anachronistic communication channel, or is it successfully implemented in existing campaign features? Is it believed to have an impact on voters, and in which ways is it perceived to supplement other campaign communications? From a political communication perspective, it is also highly interesting to compare political actors' responsive strategies with regard to their willingness to integrate mass communication and digital media communication outlets. 
Such political party attitudes toward political TV advertising may be influenced by both internal and external factors. It is plausible to believe that internal party factors, such as the campaign budget and overall campaign strategy, are important, but it may also be relevant to consider party ideology and attitudes toward advertising and commercial messages in general (Grusell \& Nord, 2010). Factors outside the party organization can also explain party standpoints. Inter-party relations may prove to be important as other parties' decisions on political TV advertising spending are followed by their political competitors (Falasca \& Grandien, 2017). It is hard to abstain from a direct communication channel if everyone else is using it. Other important external factors are regulations and laws and the technological development of new digital media platforms where political messages can be distributed (Holtz-Bacha, 2018).

The case of the comparably late political TV advertising introduction in election campaigns in Sweden may at first look as an odd deviation from normality, but could be used as an illustrative example of the hybrid nature of modern election campaigns. Contemporary campaigns are not only characterized by the addition of new digital communications to the campaign toolbox but also influenced by continuous changing mixtures of older and newer campaign practices. Thus, experiences from diverging analytical perspectives are highly valuable for the understanding of hybridization processes of election campaigns.

\section{THE STUDY}

The objective of the study is to analyze how political TV advertising develops as a campaign tool in Sweden when introduced within a highly digital communication context. The study examines Swedish election campaigns of 2006-2018 with a particular focus on party attitudes toward political TV advertising during this period and possible reasons for party argumentation related to this campaign channel. The following research questions are raised:

RQ1: How are political TV ads perceived and evaluated by political parties in Sweden in relation to other campaign communication channels in the years 2006-2018?

RQ2: How relevant are internal and external factors for political party attitudes in Sweden towards political TV ads 2006-2018?

Methodologically, the study is based on a combination of party surveys (in 2010, 2014 and in 2018) and personal interviews (in 2006, 2010, 2014 and in 2018) with Party Secretaries or Campaign Managers in all political parties represented in the Swedish parliament: The Social Democrats, The Moderate Party, The Center Party, The Liberal Party, The Christian Democrats, The Green Party, The Left Party, and The Sweden Democrats. The respondents of surveys and interviewed persons are showed in Table 1. 
Table 1. Respondents of interviews and surveys

\begin{tabular}{|c|c|}
\hline Political party & Respondents \\
\hline The Center Party & $\begin{array}{c}\text { Lena Forsman (HoC) } \\
\text { Michael Arthursson (PS) }\end{array}$ \\
\hline The Liberal Party & $\begin{array}{c}\text { Anders Andrén (HoC) } \\
\text { Maria Arnholm (PS) }\end{array}$ \\
\hline The Christian Democrats & $\begin{array}{c}\text { Acko Ankarberg Johansson } \\
\text { (PS) }\end{array}$ \\
\hline The Green Party & $\begin{array}{c}\text { Anders Wallner (PS) } \\
\text { Amanda Lind (PS) }\end{array}$ \\
\hline The Moderate Party & Per Nilsson (HoC) \\
\hline The Social Democrats & $\begin{array}{c}\text { Ibrahim Baylan (PS) } \\
\text { Bo Krogvik (HoC) } \\
\text { Nina Wadensjö (HoC) } \\
\text { John Zanchi (HoC) }\end{array}$ \\
\hline The Sweden Democrats & $\begin{array}{c}\text { Björn Söder (PS) } \\
\text { Richard Jomshoff (PS) }\end{array}$ \\
\hline The Left Party & Anki Ahlsten (PS) \\
Aron Etzler (PS)
\end{tabular}

Note: PS — Party Secretary; HoC - Head of Communications.

Source: Authors.

The party surveys were conducted in two waves, before the final campaign (June) and after election day (September-October). The surveys were based on a structured questionnaire which aimed at identifying views on party campaigns generally and with the use and views on political advertising in TV especially. The interviews were conducted as semi-structured personal interviews with a single person every party in the Swedish parliament appointed as responsible for the campaign. The interviews took place at interviewees' workplaces and lasted between 60 and 90 minutes. In total, 66 interviews were conducted and all interviews were recorded and transcribed in extenso. Interviewing for a time after an election campaign can obviously mean some source critical problems; respondents have time to forget or rebuke, overemphasize specific moments, or omit less favorable information. Since the interviews took place in less than three weeks after election day this is perceived as a minor problem in this study. The interviewed persons retrospectively reviewed and approved all quotes.

\section{EXAMINING PARTY PERCEPTIONS OF POLITICAL TV ADVERTISING}

The first research question focused on how political TV advertising was perceived and evaluated by political parties in relation to other campaign communication channels. As explained previously, political TV advertising in Sweden became a distinctive feature of the political communication context in a relatively short time. Thus, it is interesting to know how this new campaign feature has been perceived by political parties in relation to already established communication channels. In the 
following sections, party views on political TV advertising will be compared with other advertising communication channels, direct communications channels and news media communication channels.

Nowadays, Swedish political parties use a wide range of channels in order to communicate their political messages to voters. Some of them are traditional methods such as canvassing, direct mail and newspaper advertising, while others are more recently introduced such as the Internet and social media - and, in the case of Sweden, political TV advertising. In the party surveys, campaign managers were asked to rank the perceived importance of different communication channels in the election campaigns of 2010, 2014 and 2018. Starting with the campaign managers' view on different advertising communication channels three different clusters appear in Table 2.

Table 2. Party assessment of different advertising communications channels in the election campaign in the years 2010-2018 (mean values)

\begin{tabular}{|l|c|c|c|}
\hline & 2010 & 2014 & 2018 \\
\hline Television advertising & 3.5 & 3.5 & 2.6 \\
\hline Online advertising & 2.9 & 3.8 & 2.6 \\
\hline Radio advertising & 3.2 & 1.9 & 2.0 \\
\hline Cinema advertising & 1.6 & 1.8 & 2.0 \\
\hline Weekly press advertising & 2.4 & 2 & 1.9 \\
\hline Daily press advertising & 3.1 & 3.0 & 1.7 \\
\hline
\end{tabular}

Note: The question that forms the basis for the table is: “Overall, how important was your party's participation in the following communication channels?" Alternatives are on a five-point scale where $1=$ unimportant and $5=$ very important $(N=8)$.

Source: DEMICOM Election Campaign Surveys 2010, 2014 and 2018.

The first cluster includes online advertising and political TV advertising. Daily press advertising can be seen as a second group and finally weekly press, radio and cinema advertising can be seen as a third cluster. The first cluster, online and political TV advertising, receive the highest scores. Online advertising was introduced around the same time as political TV advertising. The general trend indicates that all forms of advertising in election campaigns are perceived as less important by campaign managers (except for cinema advertising). Advertising in the daily press and commercial radio has dropped significantly in perceived importance. Political TV advertising is still valuated higher than most other advertising channels, but the overall appreciation from campaign managers is rather modest. Political TV advertising plays a role in party campaign communications, but by no means a dominant role. Traditional media advertising channels have lost more of their attraction than later introduced forms of advertising, but the overall trend illustrates a declining reliance on advertising channels in general. 
When examining party campaign managers' assessments of direct communication channels in general, the results show that they rank most social media platforms, their official party web sites, direct mail, party desks and posters higher than the perceived importance of political TV advertising (Table 3). While political TV advertising was among the most appreciated advertising channels, it was among the least appreciated if other forms of direct communication with voters are included in the analysis. The general trend in the evaluation of all direct communication channels is that personal communication potentials and individual targeting possibilities are ranked higher than the overall reach of audience capacities.

Table 3. Party assessment of different direct communications channels in the election campaign in the years 2010-2018 (mean values)

\begin{tabular}{|l|c|c|c|}
\hline & 2010 & 2014 & 2018 \\
\hline Facebook & 4.2 & 4.5 & 4.7 \\
\hline Direct mail & 3.5 & 4.4 & 3.9 \\
\hline Official party websites & 4.5 & 4.6 & 3.4 \\
\hline YouTube & 4.2 & 4 & 3.4 \\
\hline Blogs & 4.4 & 2.8 & 3.3 \\
\hline Party desks in public areas & 4.1 & 4.1 & 3.1 \\
\hline Campaign/election posters & 3.6 & 4 & 3.1 \\
\hline Canvassing & 2.6 & 2.5 & 3.0 \\
\hline Television advertising & 3.5 & 3.5 & 2.6 \\
\hline Twitter & 3.8 & 3.2 & 2.4 \\
\hline
\end{tabular}

Note: The question that forms the basis for the table is: "Overall, how important was your party's participation in the following communication channels?" Alternatives are on a five-point scale where $1=$ unimportant and $5=$ very important $(N=8)$.

Source: Election Campaign Surveys 2010, 2014 and 2018.

Not surprisingly, the most popular social media platform Facebook is becoming more important for every election campaign. In 2018, no other single communication channel is perceived as more important by campaign managers. However, single social media platforms were evaluated differently during the period. The perceived importance of blogs and microblogs such as Twitter decreased. To sum up, direct communication channels seem to be valued for different reasons by party campaign managers. Some channels have a more symbolic value, while others are mostly highly rated for efficiency reasons. Party desks in public areas and election posters have been distinctive features of election campaigns in Sweden for a long time. However, both the Internet, social media and political TV advertising are later introduced within a rather short time span. It seems that political TV advertising has difficulties competing with the Internet and social media when campaign 
managers rank the importance of campaign tools. The perceived potential to involve - and interact with - voters may explain these perceptions. This opportunity to reach out with their own party messages without news media interpretations and frames seems to be important for the parties. Therefore, it is also interesting to look upon how they perceive the importance of traditional news media.

When comparing the perceived impact of political TV advertising with different news media communication channels it is obvious that all parties value all news media channels as more important communication channels than political TV advertising during election campaigns (Table 4). Appearing in news programs or in newspapers during the campaign is considered to be the best way to reach voters. There is still a robust tradition in Sweden to have journalist-led questioning and special programs with party leaders during the final weeks of the campaign, in addition to a final debate between the party leaders on public service television two days before election day.

The overall result from the party assessments of all different communication channels shows that Facebook is perceived as the most important communication channel by the parties, followed by television news and political TV programs. However, political TV advertising has, so far, not been evaluated as particularly important in comparison to other communication channels, despite its obvious potential to reach a high number of voters. The general conclusion from the investigation of campaign managers' perceptions of different communication channels is that news media continue to play a very important role, and that digital and social media with personal communication capacities are gradually becoming more important. In this highly digital campaign context, political party views on the relatively new phenomenon of political TV advertising can be described as rather ambivalent. In the next section, possible reasons for political party attitudes toward political TV advertising will be further explored.

Table 4. Party assessment of different traditional media communications channels in the election campaign in the years 2010-2018 (mean values)

\begin{tabular}{|l|c|c|c|}
\hline & 2010 & 2014 & 2018 \\
\hline Political television programs & 4.8 & 4.8 & 4.4 \\
\hline News on TV & 4.6 & 4.8 & 4.3 \\
\hline Newspaper & 4.5 & 4.6 & 3.6 \\
\hline Evening paper & 4.4 & 4.5 & 3.7 \\
\hline Local newspapers & 4.8 & 4.2 & 3.8 \\
\hline Television advertising & 3.5 & 3.5 & 2.6 \\
\hline
\end{tabular}

Note: The question that forms the basis for the table is: "Overall, how important was your party's participation in the following communication channels?" Alternatives are on a five-point scale where $1=$ unimportant and $5=$ very important $(N=8)$.

Source: Election Campaign Surveys 2010, 2014 and 2018. 


\section{EXPLORING PARTY PERCEPTIONS OF POLITICAL TV ADVERTISING}

In the following sections, party arguments for and against political TV advertising are presented. Considering external factors, it is important to remember that the parties themselves did not initiate the introduction of political TV advertising in Sweden. On the contrary, it was the commercial company TV4 who invited the parliamentary parties to broadcast political TV ads. Their offer was motivated as a form of "social contribution" and they also provided a major discount on the different TV packages that were offered. For all parties, on both political sides, the introduction was more or less unexpected at this time. The offer, in itself, was a ground-breaking event and was introduced about five months before the EP elections in 2009. The Green Party's Party Secretary Agneta Börjesson was critical of the process as such:

We think it was unacceptable to casually walk in and just "open the taps." Political $T V$ commercials are such a powerful media channel. I rather wanted us, the political parties in Sweden, to agree and find an agreement among us.

This critique was, however, not shared by the centre-right alliance who saw the introduction as something positive. The red-green parties on the other hand were overall negative and decided to abstain from political TV advertising. The internal arguments to refrain from political TV advertising varied and were viewed from several perspectives: ideologically, financially and linked to the experience from other countries in terms of smear, so-called "dirty campaigning." All this was important for the Social Democratic perspective, according to Party Secretary Ibrahim Baylan:

Our position was more of a principle character. Personally, I would have preferred that this did not become a part of Swedish political culture. I want to highlight this and to ensure that we did not start it. I do not buy the argument that it is good for voter turnout. Tell me one single country where political TV advertising dominates with higher voter turnout than Sweden. On the contrary, this is a relationship that is negative. In countries where political TV advertising is common, it often becomes very negative, and this negativity in the end drives people away from the polling stations on election day.

The Green Party and The Left party also chose to refrain from political TV advertising in 2009. The Green Party's explanation was that the party wanted to maintain campaign routines, and that they were sceptical toward this process for introducing this new form of communication with voters. They also had ideological objections. Their arguments were shared with the general viewpoints of The Left Party.

For the center-right alliance the issue of political TV advertising was less problematic. Instead, they underlined the positive effects of political TV advertising. 
Head of communication Lena Forsman, The Center Party, also pointed out that the political conflict of advertising was a fiery issue among politicians and some political journalists, but probably not a big issue among voters. The Moderates, The Christian Democrats and The Liberals, who used political TV advertising on a small scale in 2006, claimed that television as a distribution channel should not be treated differently than any other advertising campaign tool. They also argued that the fear of negative campaigning was exaggerated, and emphasized the potential of political TV advertising in mobilizing voters and increasing public awareness of the election campaign. However, there was one issue all parties could agree on: the huge costs involved in political TV advertising. All parties noted that the 2009 EP elections introductory offer could be described as a "proffer," and were completely aware of the fact that prices would probably rise significantly in the upcoming national election.

Even though there was a lot of discussion and polarized opinions about political TV advertising in 2009, all parliamentary parties decided to purchase political advertising space in TV4 before the national election in 2010. The red-green parties also produced a joint political TV ad. However, there still seemed to be a difference between the parties and their perceptions of political TV advertising, but the arguments had somewhat shifted since the previous election campaign. Internal factors, such as campaign budget and overall campaign strategy, were still important, but party ideology and attitudes toward advertising and commercial messages did not play the same significant role this time. Furthermore, the inter-party relations proved to be important as other parties' decisions on political TV advertising spending were followed by their political competitors. Bo Krogvig, Campaign Manager of The Social Democrats, declared that his party had no other choice than buying airtime on TV4, but he was still negative toward political TV advertising in general:

Political TV advertising is expensive and makes no difference! Political TV advertising does not have the same function in Sweden as it has in the United States. It's a marginal phenomenon here and costs a lot of money.

Not surprisingly, an opposite view was offered by the center-right alliance which was positive about the use of political TV advertising during the national election campaign. Erik Ullenhag, Party Secretary, The Liberal Party noted:

Political TV advertising had a substantial impact. However, my impression is that it wasn't as pervasive in 2010 as it was in the EU elections in 2009. The first reason is that people hardly knew there was an EU election until TV ads began. The second is that it was a new phenomenon. The third reason can be explained by the fact that all parties were not sending spots in the EU elections. This resulted in a high recognition factor for the political TV advertising that actually ran. 
In The Moderate Party, there were no discussions at all about using political TV advertising nationwide. Pär Henriksson, Campaign Manager, concluded:

I think it's good that we have more platforms to meet the voters. And it is natural for us to be there. So, from that perspective, it's very simple.

For all parties, external factors played a prominent role in 2010. For example, the fear of increased cost for using political TV advertising was still present and shared by all parties from the left to the right. Prices increased since the introduction in 2009, but it was still cheaper than "regular" (non-political) TV advertising. TV4 also introduced formal guidelines about how much advertising could be bought and when it could be broadcast.

It can be noted that the overall use of political TV advertising during the election campaigns in 2009, 2010, 2014 and 2018 generally can be described as fair and balanced. There were - with a few single exceptions - no open attacks and extreme examples of negative campaigning against political opponents. This may be explained by different reasons. First, this was the first time all political parties used TV spots and the overall political culture in Sweden can be described as more consensual than conflict-oriented. Second, it is also common to highlight the benefits of your own policies candidates in European campaign contexts than in the US, where more than half of all political advertising in presidential elections consists of criticism of opponents (Geer, 2006; Kaid \& Holtz-Bacha, 2006).

The party views on political TV advertising in the 2014 and 2018 national elections can be characterized as "pragmatic," and for all parties' internal factors seemed be less important in explaining party positions. The ideological dimension of the issue had more or less disappeared, and the main concerns regarding political TV advertising were related to the economic costs. Thus, two political parties, The Green Party and The Left Party, abstained from broadcasting political TV advertising and the choice to refrain was primarily connected to economics. Party Secretary Anders Wallner, The Green Party:

We tried to put ourselves in relation to traditional campaign methods and tried to find new ways for these to work out more effectively. In our opinion, the money spent on political TV advertising was not effective so we decided that this money could be used to spend on more exciting campaign features. We moved almost all of our advertising to the Internet and to social media. We identified relevant target groups of voters and had ads on digital media sites we expected our target audiences to visit.

However, for The Left Party it was a decision based more on economic aspects in conjunction with a more decentralized party organisation. Party Secretary Aron Etzler: 
I do think it could have been a different election outcome if we had paid for political $T V$ ads. We had direct mails to households that we centrally wanted to abolish. But it was met with resistance from all the regional party districts and they are the ones in charge of the money. The only thing we could do was to say, we think you can do something better with this money. But that did not happen.

Overall the view on political TV-advertising was rather pragmatic among the red-green parties. Nina Wadensjö, Campaign Manager, The Social Democrats:

Now it is there, and then we do as a professional job as we can.

To conclude, the introduction of political TV advertising in Sweden has traveled across the spectrum from controversial to non-controversial in a very short period of time. From being absent in preceding election campaigns it reached a majority of voters in the election campaigns of 2006-2018. During these years different factors, both internal and external, have been significant for the parties' standpoints on this issue (Table 5).

Table 5. General overview of the parties' arguments on political TV advertising in the years 2006-2018

\begin{tabular}{|l|c|c|c|c|c|c|}
\hline \multirow{2}{*}{} & \multicolumn{3}{|c|}{ Center-right alliance } & \multicolumn{3}{c|}{ Red-green parties } \\
\cline { 2 - 7 } & $\begin{array}{c}\text { Overall } \\
\text { standpoint }\end{array}$ & $\begin{array}{c}\text { Internal } \\
\text { factors }\end{array}$ & $\begin{array}{c}\text { External } \\
\text { factors }\end{array}$ & $\begin{array}{c}\text { Overall } \\
\text { standpoint }\end{array}$ & $\begin{array}{c}\text { Internal } \\
\text { factors }\end{array}$ & $\begin{array}{c}\text { External } \\
\text { factors }\end{array}$ \\
\hline $\mathbf{2 0 0 6}$ & + & - & $\begin{array}{c}\text { Media } \\
\text { regulations, } \\
\text { digitaliza- } \\
\text { tion }\end{array}$ & 0 & - & - \\
\hline $\begin{array}{l}\text { EU } \\
\text { elections }\end{array}$ & + & $\begin{array}{c}\text { Party } \\
\mathbf{2 0 0 9}\end{array}$ & $\begin{array}{c}\text { Media } \\
\text { idegulations, } \\
\text { digitaliza- } \\
\text { tion }\end{array}$ & - & $\begin{array}{c}\text { Party } \\
\text { ideology, } \\
\text { economy }\end{array}$ & $\begin{array}{c}\text { Media } \\
\text { regulations, } \\
\text { digitaliza- } \\
\text { tion }\end{array}$ \\
\hline $\begin{array}{l}\text { National } \\
\text { elections } \\
\mathbf{2 0 1 0}\end{array}$ & + & $\begin{array}{c}\text { Party } \\
\text { ideology }\end{array}$ & $\begin{array}{c}\text { Campaign } \\
\text { develop- } \\
\text { ments }\end{array}$ & + & Economy & $\begin{array}{c}\text { Campaign } \\
\text { develop- } \\
\text { ments }\end{array}$ \\
\hline $\begin{array}{l}\text { National } \\
\text { elections } \\
\mathbf{2 0 1 4}\end{array}$ & + & $\begin{array}{c}\text { Party } \\
\text { ideology }\end{array}$ & $\begin{array}{c}\text { Campaign } \\
\text { develop- } \\
\text { ments }\end{array}$ & $+/-$ & Economy & $\begin{array}{c}\text { Campaign } \\
\text { develop- } \\
\text { ments }\end{array}$ \\
\hline $\begin{array}{l}\text { National } \\
\text { elections } \\
\mathbf{2 0 1 8}\end{array}$ & + & $\begin{array}{c}\text { Party } \\
\text { ideology }\end{array}$ & $\begin{array}{c}\text { Campaign } \\
\text { develop- } \\
\text { ments }\end{array}$ & $+/-$ & Economy & $\begin{array}{c}\text { Campaign } \\
\text { develop- } \\
\text { ments }\end{array}$ \\
\hline
\end{tabular}

Note: $-=$ negative,$+=$ positive,$+/-=$ mixed, $0=$ indifferent.

Source: Authors. 
Basically, changing regulations for the commercial TV channel TV4 opened the way for political TV advertising in Sweden. The parties were not prepared for producing spots, but some parties adapted to the new situation more rapidly than others. Overall, there are differences in views on political TV advertising between non-socialist parties and parties on the left side of the political spectrum. Liberals and Moderates have never expressed any ideological concerns regarding political TV advertising. They have argued that television should have the same possibility as other media to include political ads. Furthermore, non-socialist politicians have played down fears that political TV advertising in Sweden could develop in an "American" direction with a large proportion of negative ads.

In contrast, left-wing and green politicians have expressed both ideological and economic concerns about political TV advertising, even if the costs seem to be considered as the main problem in recent years. The red-green parties have reluctantly decided to follow their political opponents into the new communication channel, and accepted that political TV advertising is now established during Swedish election campaigns. They do not like this communication channel, but realize they have to deal with it in the same professional way as their political opponents.

Political party positions have also been influenced by the changing election campaign context. Political TV advertising was introduced in Swedish election campaigns at the same time as digital media developed rapidly. During the 2006 election campaign, blogs became a new campaign feature and four years later microblogs were referred to as being a possible game changer in the campaign. In 2018, most Swedish voters were using smartphones, making mobile political communications more important than ever. This means that political TV advertising had to compete with other new communication channels during this period. Consequently, political parties have developed their campaign toolboxes with slightly different mixtures of old and new communication capacities.

\section{CONCLUSIONS: PARTIES PRESSED BETWEEN THE PAST AND THE PRESENT}

The objective of this study was to analyze how political television advertising has developed as a campaign tool when introduced within a highly digital communication context. The first research question asked how political TV advertising was perceived and evaluated by political parties in Sweden in relation to other campaign communication channels. The results show that political TV advertising has been gradually implemented in the campaign context. Campaign managers have limited expectations on this communication channel and perceive it as less important than news media and social media channels. Despite the fact that political TV advertising offers hitherto unknown possibilities to reach a large number of voters directly it seems to play a rather limited role in overall campaign strategies.

The second research question asked how relevant different factors were for political party attitudes in Sweden towards political TV advertising. The results indicate 
that both ideological and financial considerations have been important when explaining the overall critical attitudes among left-wing parties. However, all parties seem to have evaluated political TV advertising within the current campaign context. This new direct communication channel has been faced with double challenges when introduced: Firstly, news media coverage of elections in Sweden has always been perceived as extremely important and decisive for voter decisions, while general public attitudes toward advertising have been more skeptical. Secondly, the dramatically increased supply of digital and social media platforms offering excellent direct communication interactions between parties and voters make political TV advertising less valuable in the campaign toolbox. Pressed between the historical importance of traditional news media and the new expectations on digital media, political TV advertising has played a more modest role in Swedish election campaigns in comparison to many other democratic countries.

Even if the results indicate a moderate impact of political TV advertising in Sweden, it has in a short time span become a relevant tool for most parties' mix of communication channels. In recent years, there have also been increasing speculations whether new forms of direct communication will finally replace the strong news media dominance and traditional campaign methods. Today, all political parties use the Internet and social media extensively, both as a channel to target specific voter segments and as tools to increase interest in various party activities. There is, however, a big difference between the perceptions of digital and social media compared to political TV advertising. Digital and social media are perceived to have a greater potential to involve and interact with voters.

From a digitalization perspective, these trends may be further strengthened. In the new media environment, campaign communications become more diverse; media use is more individual and audiences more fragmented. Consequently, the new media landscape is becoming increasingly segmented. For example, with a clear shift to on-demand TV viewing it is possible that political TV advertising has a very bleak future. At the same time, television was in 2016 replaced by the Internet as the most important source of information among Swedes (Davidsson \& Findahl, 2016). Thus, it is not entirely unreasonable to predict that political parties will gradually abandon political TV advertising in the future for other campaigning methods that are perceived as more effective.

Besides media developments, the future of political TV advertising depends on economic resources. Political TV advertising is very expensive and it is reasonable to expect that political parties will judge the value of TV advertising versus price. In this area, it is also likely that digital and social media will appear as heavy challengers when parties decide where to spend advertising money.

This case study of Sweden may serve as an illustrative example of the hybrid nature of modern election campaigns. Contemporary campaigns are not only characterized by the constant addition of new digital communications to the toolbox, they are also influenced by continuous changing mixtures of older and newer 
campaign practices. The unexpected introduction of political TV advertising, at the same time as digital and social media appeared as communication channels, makes Sweden an interesting case. This study can therefore be seen as a valuable contribution to the understanding of changes in contemporary election campaigns practices and the ongoing processes of hybridization.

\section{REFERENCES}

Blumler, J. G. (2013). The fourth age of political communication. Retrieved July 23, 2018, from https:// doaj.org/article/bc2cbd793f5f4f52856709c7978b62bc.

Brants, K., \& Voltmer, K. (Eds.). (2011). Political communication in postmodern democracy: Challenging the primacy of politics. Basingstoke: Palgrave Macmillan.

Chadwick, A. (2013). The hybrid media system: Politics and power. Oxford: Oxford University Press.

Chadwick, A., \& Stromer-Galley, J. (2016). Digital media, power and democracy in parties and election campaigns: Party decline or party renewal? The International Journal of Press/Politics, 3, 283-293.

Dalton, R. J. (2008). Citizen politics: Public opinion and political parties in advanced industrial democracies. Washington DC: CQ Press.

Davidsson, P., \& Findahl, O. (2016). Svenskarna och internet 2016 [The Swedes and the Internet 2016]. Stockholm: Internetstiftelsen i Sverige, IIS.

Engblom, L. Å., \& Wormbs, N. (2007). Radio och TV efter monopolet [Radio and TV after the monopoly]. Stockholm: Etermedierna i Sverige/Ekerlids förlag.

Esser, F., \& Pfetsch, B. (Eds.). (2004). Comparing political communication: Theories, cases, and challenges. Cambridge: Cambridge University Press.

Falasca, K., \& Grandien, C. (2017). "Where you lead we will follow." A longitudinal study of strategic political communication in election campaigning. Journal of Public Affairs, 17, 1-10.

Fridkin, K. L., \& Kenney, P. J. (2012). The impact of negative campaigning on citizens' actions and attitudes. In H. Semetko \& M. Scammel (Eds.), The Sage handbook of political communication (pp. 173-185). London: Sage Publishing.

Geer, J. G. (2006). In defense of negativity: Attack ads in presidential campaigns. Chicago: University of Chicago Press.

Grusell, M., \& Nord, L. (2010). More cold case than hot spot: A study of public opinion on political advertising in Swedish television. Nordicom Review, 2, 95-111.

Grusell, M., \& Nord, L. (2016). Setting the trend of changing the game? Professionalization and digitalization of election campaigns. Journal of Political Marketing. https://doi.org/10.1080/15377857. 2016.1228555 .

Holbert, R. L., Benoit, W. L., Hansen, G. J., \& Wen, C.-W. (2002). The role of communication in the formation of an issue-based citizenry. Communication Monographs, 69, 263-310.

Holtz-Bacha, C. (2018). Political advertising - a research overview. Central European Journal of Communication, 11(2), 166-176.

Jungherr, A. (2016). Four functions of digital tools in election campaigns: The German case. The International Journal of Press/Politics, 21, 358-377.

Kaid, L. L. (2008). Political advertising. In L. L. Kaid (Ed.), Handbook of political communication research (pp. 155-202). Mahwah: Lawrence Erlbaum.

Kaid, L. L., \& Holtz-Bacha, C. (Eds.). (2006). The Sage handbook of political advertising. London: Sage Publishing.

Karvonen, L., \& Kuhnle, S. (Eds.). (2001). Party systems and voter alignments revisited. London: Routledge. 
Lilleker, D. G., Tenscher, J., \& Stetka, V. (2014). Towards hypermedia campaigning? Perceptions of new media's importance for campaigning by party strategists in comparative perspective. Information, Communication \& Science, 18, 747-765.

Magin, M., Podschuweit, N., Hassler, J., \& Russmann, U. (2017). Campaigning in the fourth age of political communication: A multi-method study on the use of Facebook by German and Austrian parties in the 2013 election campaigns. Information, Communication \& Society, 20(11), 16981719. https://doi.org/10.1080/1369118X.2016.1254269.

Negrine, R., \& Stanyer, J. (Eds.). (2007). The political communication reader. London: Routledge.

Nord, L. (2008). Medier utan politik. De svenska riksdagspartiernas syn på dagspress, radio och TV [Media without policy. Swedish political party views on press, radio and TV]. Stockholm: Santérus Förlag.

Nord, L. (2009). Political campaign communication in Sweden: Change, but not too much. Central European Journal of Communication, 2(2), 233-250.

Plasser, F., \& Plasser, G. (2002). Global political campaigning: A worldwide analysis of campaign professionals and their practices. Westport: Praeger Publishers.

Skirbekk, T. (2015). Hvordan vinne valg. Moderne politisk kommunikasjon [How to win elections. Modern political communication]. Oslo: Spartacus.

Swanson, D. L., \& Mancini, P. (Eds.). (1996). Politics, media, and modern democracy: An international study of innovations in electoral campaigning and their consequences. Westport: Greenwood Publishing Group.

Towner, T. L., \& Dulio, D. A. (2012). New media and political marketing in the United States: 2012 and beyond. Journal of Political Marketing, 11, 95-119. 